\title{
The Post-Reperfusion Syndrome (PRS): Diagnosis, Incidence and Management
}

\author{
Kyota Fukazawa and Ernesto A. Pretto, Jr. \\ University of Miami, Miller School of Medicine, Miami, Florida \\ USA
}

\section{Introduction}

Despite the remarkable advances in the peri-operative management of the liver transplant recipient, the post-reperfusion syndrome (PRS) continues to be an important intraoperative risk factor for impaired graft function, and morbidity and mortality of the recipient. In order to institute preventive measures several studies have attempted to elucidate risk factors for PRS. Those identified risk factors and proposed mechanisms underlying the development of PRS, as well as current issues with PRS will be discussed in the following three sections.

\section{Diagnosis}

The post-reperfusion syndrome (PRS) which occurs during liver transplantation was first diagnosed by Aggarwal et al in 1987 and described as cardiovascular collapse following revascularization of the liver graft. They defined PRS as severe hemodynamic instability, persistent hypotension (a greater than 30\% drop below the anhepatic mean arterial blood pressure (MAP) within 5 minutes of reperfusion and sustained for at least 1 minute), accompanied by asystole, or significant arrhythmias as well as development of significant, fibrinolysis requiring treatment. Up until now this definition remains the same with some modifications. Hilmi et al defined mild PRS as a drop in MAP to less than $30 \%$ of mean baseline MAP observed during the anhepatic stage associated with bradycardia and sustained for less than 5 minutes, and requiring calcium or epinephrine boluses, but without the need for continuous vasopressor infusion. Severe PRS was defined as persistent severe hypotension with a greater than $30 \%$ reduction in MAP from mean baseline MAP during the anhepatic stage, associated with asystole, significant arrhythmias, and requiring prolonged vasopressor infusion (until end of surgery) and fibrinolysis. Other reports have used only persistent hypotension as the defining endpoint for PRS. Therefore, inconsistency of definitions makes it difficult to draw conclusions concerning the precise incidence of PRS, its clinical presentation and causes.

These definitions rely on the value of the percent change in MAP from the mean baseline MAP observed during the anhepatic stage. It so happens that the anhepatic stage is fraught with hemodynamic fluctuations related to manipulation of the inferior vena cava (IVC), blood loss, veno-venous bypass, hypothermia, metabolic acidosis, etc., which are common during the an-hepatic phase. These multi-factorial hemodynamic perturbations call into 


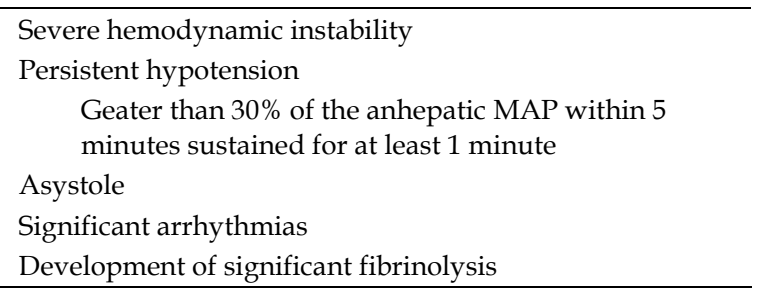

Table 1. Definition of Post-Reperfusion Syndrome (PRS) Abbreviations: MAP: Mean Arterial Blood Pressure

question the reliability and accuracy of PRS incidence and severity based on one parameter namely, \% change in MAP. Moreover, pre-treatment with bolus doses of vasopressors, including calcium chloride, vasopressin or methylene blue immediately prior to reperfusion of the portal vein, intended to preempt severe hypotension post-reperfusion also introduce errors into the calculation of \% changes in MAP, before and after reperfusion. More importantly, in some instances there may be a complete absence of hemodynamic instability even in the presence of severe graft dysfunction following reperfusion when portal vein flow is inadequate. This is called the no-reflow phenomenon. No-reflow is associated with high vascular resistance in the microcirculation of the graft secondary to multiple factors, such as: tissue edema, leukocyte plugging and the accumulation of pro-inflammatory factors and cellular debris; vasoconstriction of the tissues due to cold preservation, portal vein thrombosis, or presence of large collateral veins (porto-systemic shunts). In those cases, there is a gradual resolution of no-reflow and hemodynamic fluctuations may be delayed beyond the immediate portal vein or even hepatic artery reperfusion periods when the organ is better perfused. For these reasons, PRS incidence may not be accurately ascertained when a narrow window of MAP readings is used in its determination. Likewise, major changes in MAP in the immediate post-reperfusion period may or may not be associated with graft quality. Although cardiovascular collapse following reperfusion is common in liver transplant practice, it is essential to elucidate the underlying mechanisms of PRS, and to determine more accurately the relationship between PRS and graft quality. Is PRS a cause of poor graft quality or is it a consequence? The definitive answer to this question can only be found in the conduct of a blinded controlled prospective study with well-defined end points in a large cohort of patients. The results of such a study would help to broaden the scope of what constitutes the diagnosis of PRS.

\section{Incidence of PRS and confounding factors}

To date, there is wide variation in the reported incidence of PRS (5.9-61.3\%). There are several factors attributable to these wide variations, among these are: differences in surgical technique, intraoperative hemodynamic management, as well as chronological and geographical factors. Piggyback technique is used for implantation of the liver graft without interrupting IVC flow. It was first introduced into human liver transplantation in the late 1980 's. Veno-venous bypass (VVB) was also introduced in the 1980's. Those techniques were developed to enable more stable hemodynamics upon manipulation of the IVC during orthotopic liver transplantation. Because volume status of the recipient before reperfusion can be an important risk factor for PRS, more stable hemodynamics before reperfusion may decrease its incidence, although the impact of surgical technique between conventional or 


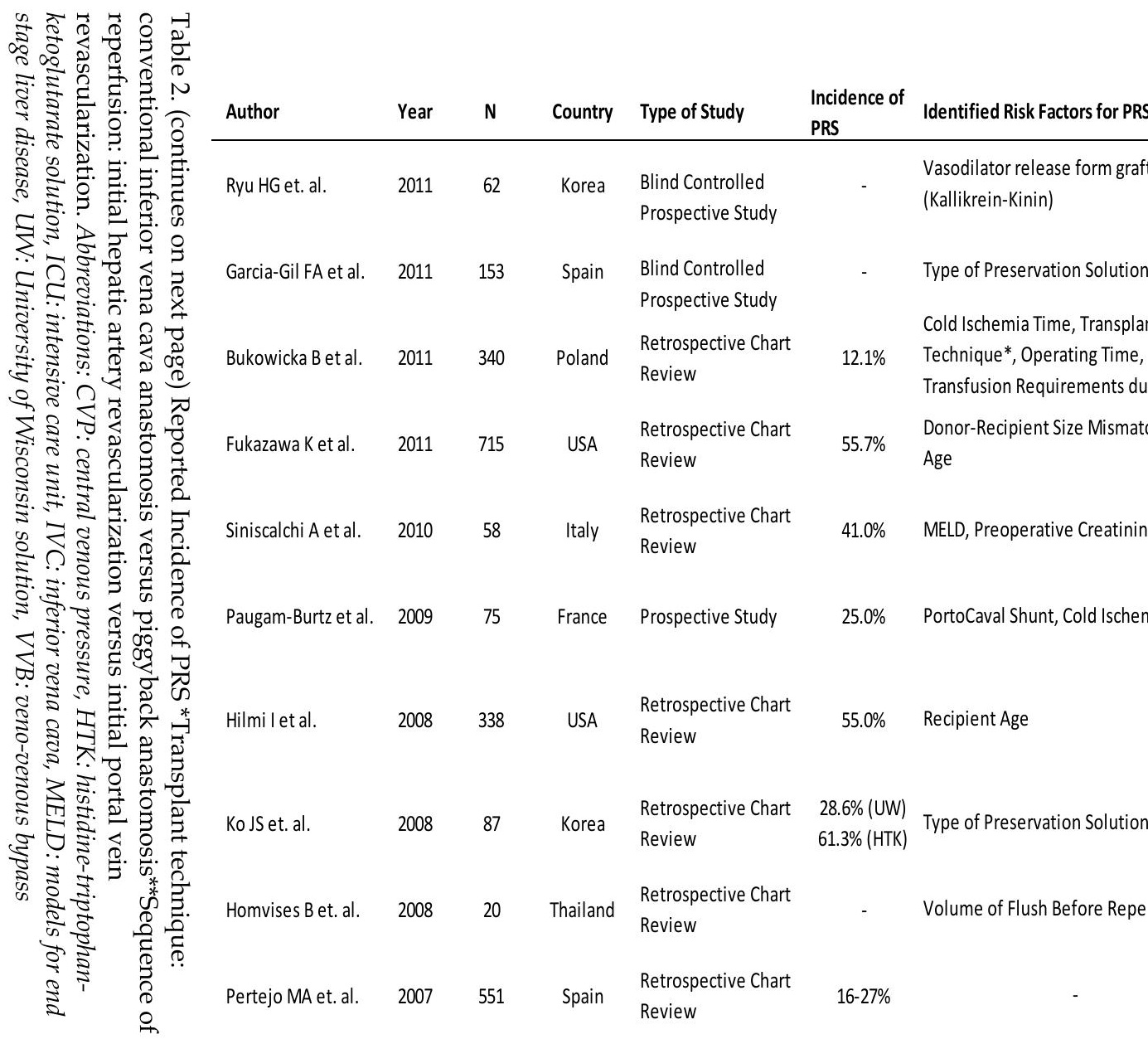




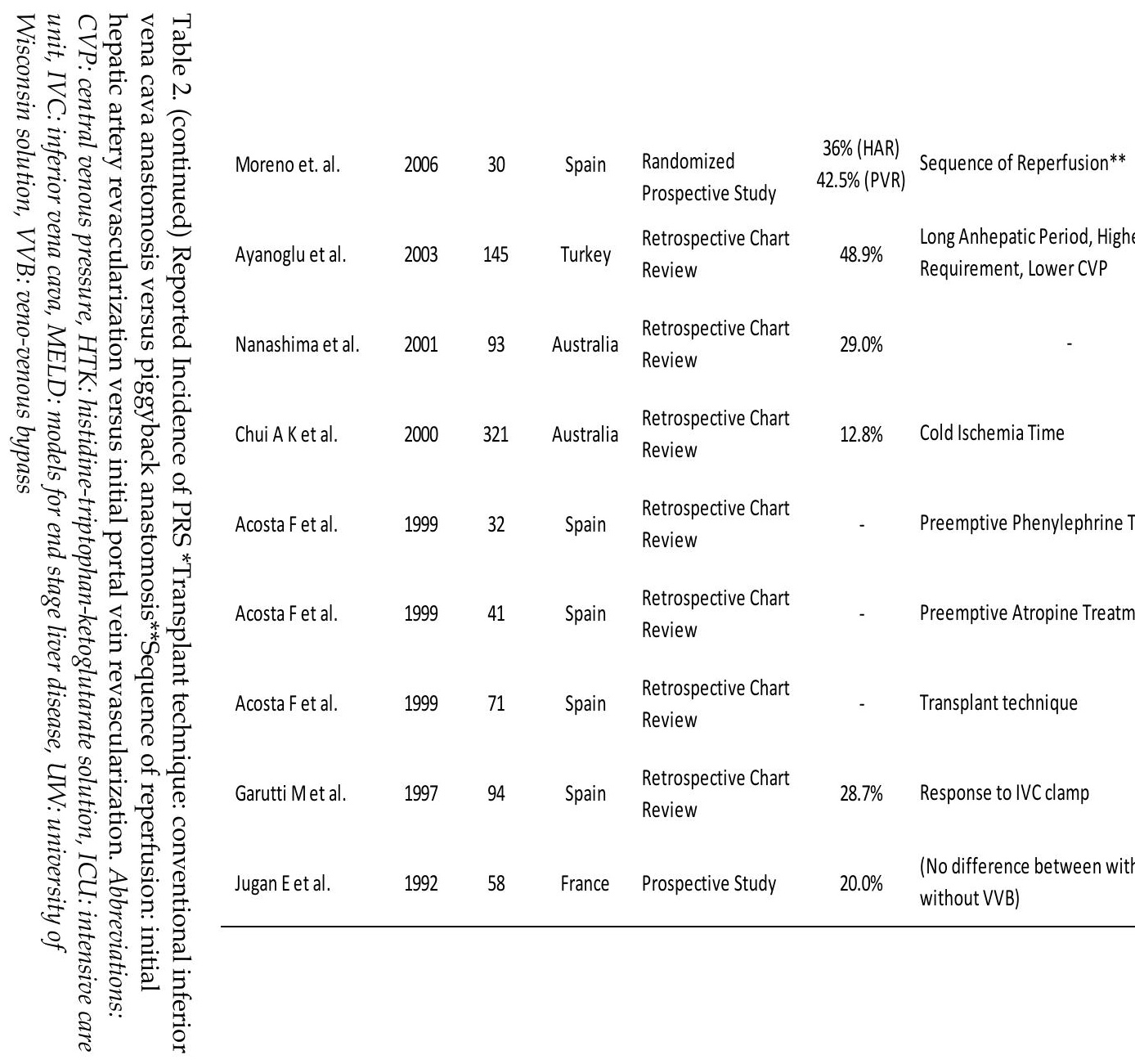


piggy-back techniques on PRS is still in debate. In addition, VVB reduces small bowel edema, which has been suggested as a primary site for the production and release of potent vasoactive inflammatory mediators. With the improvement of transplant outcomes and recognition of risk factors for graft survival, expanded criteria donors (ECD) have been more frequently used due to severe shortages of organ donors. More frequent usage of ECD as well as the introduction of new surgical techniques may affect the incidence of PRS, depending on the era, a chronological factor. Also, geographical areas with low organ donor conversion rates and acute shortage of organs for transplantation will invariably result in higher usage rates of ECD, as well as sicker recipients due to longer waiting times. Therefore, the incidence of PRS will vary with geographical area. The interpretation of those results also needs to take chronological and geographical factors into account as confounding factors.

\section{Risk factors for PRS}

Well-established risk factors and recognized mechanisms associated with PRS include: i) volume status of the recipient before reperfusion, ii) myocardial depression due to embolization of cold preservation solution into the systemic circulation, and iii) release of vasoactive pro-inflammatory factors originating in activated Kupffer cells of the postischemic liver graft.

\subsection{Pre-reperfusion volume status}

The liver is an important reservoir of blood, containing a total of about $250-500 \mathrm{ml}$ or 18 $30 \mathrm{ml} / 100 \mathrm{~g}$ of blood. In liver transplantation, the donor liver graft will be rapidly filled with recipient blood following revascularization of the portal vein, resulting in immediate volume shifts and occasionally, hypotension. De La Morena et al. determined that an insufficient increase in preload is a main causative factor of PRS (or reperfusion hypotension) in an observational study using transesophageal echocardiography (TEE). Maintaining a high cardiac output is essential to ensure adequate perfusion of organs in liver transplantation. However, high cardiac output can be accomplished by maintaining preload, which may be difficult given that the operation itself is associated with major changes in volume and afterload, in addition to blood loss, third space losses, and ongoing ascites production. This result will support the hypothesis that volume shift is one of the main components of reperfusion hypotension and maintaining adequate preload before reperfusion is crucial. Also, size mismatch between donor and recipient can cause additional volume shifts, as evidenced by the fact that a large-for-size donor relative to recipient body size causes more severe reperfusion hypotension. The BSA index (BSAi) may help to more accurately match donor and recipient organs in whole organ liver transplantation.

\subsection{Myocardial performance}

In addition to volume shifts, a change in myocardial performance is another component of reperfusion hypotension/PRS. Myocardial performance is reduced by a decrease in temperature, acid-base and electrolyte disturbances, which are all caused by the flushing of residual preservation solution into the systemic circulation after revascularization of the graft. Acidosis following reperfusion due to release of acidic fluid from ischemic bowel and liver graft is a common finding in liver transplantation. Acute acidosis can cause 
tachycardia, dysrrythmias, and severe myocardial depression by producing changes in resting membrane potential and threshold potential and an increase in the rate of phase IV depolarization. Therefore the use of VVB has been proposed to decrease the incidence of PRS by minimizing small bowel edema/ischemia with varying results.

\subsection{Donor factors}

Lastly, the release of inflammatory factors from the post-ischemic donor liver graft into the recipient systemic circulation also can trigger a systemic inflammatory chain reaction that can lead to systemic hypotension and multi-organ dysfunction. Therefore, the quality of the donor can be a risk factor for PRS, and postoperative graft function (primary non-function, and graft survival). A donor organ with certain characteristics such as extreme age, adverse past medical history, preexisting liver damage or disease, obesity, hemodynamic instabilities, deceased cardiac donor (DCD), risk of sepsis and malignancies, hypernatremia, and prolonged ICU stay, may be more susceptible to ischemia, and more likely to have higher incidence of primary non-function (PNF), delayed function or subsequent risk for reduction in long-term graft survival. Similarly, several studies have attempted to identify donor risk factors for PRS. Hilmi et al reported warm ischemia time as a risk factor and more recently Paugam-Burtz, et al reported cold ischemia time is also a risk for PRS. In addition to those prior studies, donor age is an important risk factor for PRS. The older donor graft has a lower tolerance for hypoxia, and a greater susceptibility to reperfusion injury, probably due to metabolic changes associated with senescence, age related atherosclerotic changes in vascular structures, or steatotic changes of the parenchyma. The type of preservation solution and the graft flushing techniques have also been shown to affect the severity of PRS.

\section{Strategy for the intraoperative management of PRS}

Warm recipient blood flows into the cold organ after revascularization of the portal vein, causing immediate volume shifts, re-oxygenation of the ischemic organ, and outflow of cold preservation solution saturated with vasoactive pro-inflammatory factors. Optimization of volume status in the recipient prior to reperfusion may minimize hemodynamic changes related to volume shifts by maximizing hemodynamic capacity to maintain good perfusion pressure throughout the liver graft, especially the large-for-size graft. TEE coupled with close monitoring of hemodynamic parameters with continuous cardiac output (CO)/SvO2, and standard cardiac monitors are particularly helpful to ensure hemodynamic integrity of the recipient. To obtain sufficient perfusion of the liver graft, especially through the hepatic microcirculation, vasodilating agents such as prostaglandin or calcium channel blockers can be used but with caution since those agents can aggravate hemodynamic instability. To minimize the sudden outflow of preservation solution from the liver graft, flushing the organ prior to reperfusion has been used and currently proposed as the most effective way of preventing hemodynamic instability associated with the inadvertent release of preservation solution. Ingredients of the flush solution as well as rate of infusion, temperature of flush solution, and amount of solution are still under investigation. Gradual and homogeneous perfusion of the organ by machine perfusion immediately prior to implantation may improve graft function by effectively removing the pro-inflammatory factors from the graft microcirculation, may reduce PRS and improve short and long term graft survival, especially in the ECD. Preemptive use of vasopressors may help maintain the 
systemic blood pressure but may not improve the \% change in blood pressure or graft outcome. Preemptive use of oxidative free radical scavenging agents or attempts at counteracting vasoactive inflammatory factors is another area of research. For example, methylene blue has been used to scavenge nitric oxide related vasodilation in various shock states. Also, several oxidative free radical scavengers, vasodilators (inhaled nitric oxide, prostaglandin E), and Ibuprofen (cyclooxygenase inhibitor) have been studied as a way to suppress the pro-inflammatory cascade post-reperfusion. The benefits of these treatment strategies on PRS and postoperative graft function are inconclusive, and larger clinical trials are needed. This will require a consortium of leading academic liver transplant centers to conduct multicenter clinical trials. To minimize the impairment of cardiac performance following reperfusion, electrolyte abnormalities, especially hypocalcemia and hyperkalemia need to be corrected prior to reperfusion. Magnesium replacement may need to be considered, especially when there is hypocalcemia due to intraoperative transfusion and citrate intoxication. Citrate binds magnesium as well as calcium, causing acute hypomagnesemia.

\section{Conclusions}

After having contributed to the establishment of liver transplantation as a safe and definitive treatment option for patients with end stage liver disease, including those with ESLD complicated by hepatocarcinomas, in the latter half of the $20^{\text {th }}$ century, the next challenge to Transplant Anesthesiologists and Critical Care Specialists in the $21^{\text {st }}$ is to continue to improve the perioperative management of the donor and organ transplant recipient during the most critical period of the liver transplant procedure namely, revascularization, reperfusion and re-oxygenation of the graft. This effort will undoubtedly require multicenter research collaborations, the determination of better and more reliable end-points for PRS and graft function, and the institution and conduct of multicenter clinical trials. Inevitably research will most likely reveal the need for a multi-factorial treatment strategy to preempt or mitigate PRS and the deterioration of graft function, especially of the ECD graft. This effort comprises preconditioning of the donor, preservation and post condition of the recipient transplanted, a process that can be succinctly described as 'organ resuscitation'. Better post-transplant outcomes will decrease the costs involved in retransplantation, and prolonged ICU and hospital stays.

\section{References}

Acosta, F., Rodriguez, M. A., Sansano, T., Contreras, R. F., Reche, M., Roques, V., Beltran, R., Robles, R., Bueno, F. S., Ramirez, P. \& Parrilla, P. (1999). Influence of surgical technique on postreperfusion syndrome during liver transplantation. Transplant Proc, 31, 6, (Sep,1999), pp. 2380-2381,0041-1345 (Print) 0041-1345 (Linking)

Acosta, F., Sansano, T., Contreras, R. F., Reche, M., Beltran, R., Roques, V., Rodriguez, M. A., Robles, R., Bueno, F. S., Ramirez, P. \& Parrilla, P. (1999). Atropine prophylaxis of the postreperfusion syndrome in liver transplantation. Transplant Proc, 31, 6, (Sep,1999), pp. 2377,0041-1345 (Print) 0041-1345 (Linking)

Acosta, F., Sansano, T., Contreras, R. F., Reche, M., Roques, V., Beltran, R., Rodriguez, M. A., Robles, R., Bueno, F. S., Ramirez, P. \& Parrilla, P. (1999). Phenylephrine treatment of the postreperfusion syndrome in liver transplantation. Transplant Proc, 31, 6, (Sep,1999), pp. 2373-2374,0041-1345 (Print) 0041-1345 (Linking) 
Aggarwal, S., Kang, Y., Freeman, J. A., Fortunato, F. L. \& Pinsky, M. R. (1987). Postreperfusion syndrome: cardiovascular collapse following hepatic reperfusion during liver transplantation. Transplant Proc, 19, 4 Suppl 3, (Aug,1987), pp. 5455,0041-1345 (Print) 0041-1345 (Linking)

Ayanoglu, H. O., Ulukaya, S. \& Tokat, Y. (2003). Causes of postreperfusion syndrome in living or cadaveric donor liver transplantations. Transplant Proc, 35, 4, (Jun,2003), pp. 1442-1444,0041-1345 (Print) 0041-1345 (Linking)

Blankensteijn, J. D., Schlejen, P. M., Groenland, T. H. \& Terpstra, O. T. (1992). The effects of long-term graft preservation and prostaglandin E1 on intraoperative hemodynamic changes in liver transplantation. A comparison between orthotopic and heterotopic transplantation in the pig. Transplantation, 54, 3, (Sep,1992), pp. 423-428,0041-1337 (Print) 0041-1337 (Linking)

Bukowicka, B., Abi Akar, R., Olszewska, A., Smoter, P. \& Krawczyk, M. (2011). The occurrence of postreperfusion syndrome in orthotopic liver transplantation and its significance in terms of complications and short-term survival. Ann Transplant, 16, 2, (Jun 30,2011), pp. 26-30,1425-9524 (Print) 1425-9524 (Linking)

Chui, A. K., Shi, L., Tanaka, K., Rao, A. R., Wang, L. S., Bookallil, M., Mayr, M., Chiu, E., Verran, D. J., Mears, D. \& Sheil, A. G. (2000). Postreperfusion syndrome in orthotopic liver transplantation. Transplant Proc, 32, 7, (Nov,2000), pp. 21162117,0041-1345 (Print) 0041-1345 (Linking)

Clements, S. D., Jr. \& Hurst, J. W. (1972). Diagnostic value of electrocardiographic abnormalities observed in subjects accidentally exposed to cold. Am J Cardiol, 29, 5, (May,1972), pp. 729-734,0002-9149 (Print) 0002-9149 (Linking)

Cordovi de Armas, L., Jimenez Paneque, R. E., Gala Lopez, B., Rapalo Romero, E. I., Anuez Castillo, Y. \& Vallongo Menendez, M. B. (2010). Rapid and homogeneous reperfusion as a risk factor for postreperfusion syndrome during orthotopic liver transplantation. Rev Bras Anestesiol, 60, 2, (Apr,2010), pp. 154-161, 188-192,1806907X (Electronic) 0034-7094 (Linking)

de la Morena, G., Acosta, F., Villegas, M., Bento, M., Sansano, T., Bueno, F. S., Ramirez, P., Ruiperez, J. A. \& Parrilla, P. (1994). Ventricular function during liver reperfusion in hepatic transplantation. A transesophageal echocardiographic study. Transplantation, 58, 3, (Aug 15,1994), pp. 306-310,0041-1337 (Print) 0041-1337 (Linking)

Diaz, J., Acosta, F., Parrilla, P., Sansano, T., Tornel, P. L., Robles, R., Ramirez, P., Bueno, F. S. \& Martinez, P. (1996). Serum ionized magnesium monitoring during orthotopic liver transplantation. Transplantation, 61, 5, (Mar 15,1996), pp. 835-837,0041-1337 (Print) 0041-1337 (Linking)

Evgenov, O. V. \& Bjertnaes, L. J. (2003). Administration of methylene blue in human septic shock: renaissance of an old drug? Crit Care Med, 31, 5, (May,2003), pp. 1601-1602; author reply 1602,0090-3493 (Print) 0090-3493 (Linking)

Fukazawa, K., Nishida, S., Volsky, A., Tzakis, A. G. \& Pretto, E. A., Jr. (2011). Body surface area index predicts outcome in orthotopic liver transplantation. J Hepatobiliary Pancreat Sci, 18, 2, (Mar,2011), pp. 216-225,1868-6982 (Electronic)

Fukazawa, K. \& Pretto, E. A. (2011). The effect of methylene blue during orthotopic liver transplantation on post reperfusion syndrome and postoperative graft function. J Hepatobiliary Pancreat Sci, 18, 3, (May,2011), pp. 406-413,1868-6982 (Electronic) 
Garcia-Gil, F. A., Serrano, M. T., Fuentes-Broto, L., Arenas, J., Garcia, J. J., Guemes, A., Bernal, V., Campillo, A., Sostres, C., Araiz, J. J., Royo, P. \& Simon, M. A. (2011). Celsior versus university of wisconsin preserving solutions for liver transplantation: postreperfusion syndrome and outcome of a 5-year prospective randomized controlled study. World J Surg, 35, 7, (Jul,2011), pp. 1598-1607,14322323 (Electronic) 0364-2313 (Linking)

Grazi, G. L., Cescon, M., Ravaioli, M., Ercolani, G., Pierangeli, F., D'Errico, A., Ridolfi, L., Cavallari, A. \& Mazziotti, A. (2001). A revised consideration on the use of very aged donors for liver transplantation. Am J Transplant, 1, 1, (May,2001), pp. 6168,1600-6135 (Print)

Griffith, B. P., Shaw, B. W., Jr., Hardesty, R. L., Iwatsuki, S., Bahnson, H. T. \& Starzl, T. E. (1985). Veno-venous bypass without systemic anticoagulation for transplantation of the human liver. Surg Gynecol Obstet, 160, 3, (Mar,1985), pp. 270-272,0039-6087 (Print) 0039-6087 (Linking)

Hilmi, I., Horton, C. N., Planinsic, R. M., Sakai, T., Nicolau-Raducu, R., Damian, D., Gligor, S. \& Marcos, A. (2008). The impact of postreperfusion syndrome on short-term patient and liver allograft outcome in patients undergoing orthotopic liver transplantation. Liver Transpl, 14, 4, (Apr,2008), pp. 504-508,1527-6473 (Electronic) 1527-6465 (Linking)

Himmelreich, G., Hundt, K., Neuhaus, P., Bechstein, W. O., Roissant, R. \& Riess, H. (1993). Evidence that intraoperative prostaglandin E1 infusion reduces impaired platelet aggregation after reperfusion in orthotopic liver transplantation. Transplantation, 55, 4, (Apr,1993), pp. 819-826,0041-1337 (Print) 0041-1337 (Linking)

Homvises, B., Sirivatanauksorn, Y., Limsrichamrern, S., Pongraweewan, O., Sujirattanawimol, K. \& Raksakietisak, M. (2008). The minimal flush volume for washout of preservation fluid in liver transplantation. Transplant Proc, 40, 7, (Sep,2008), pp. 2123-2126,0041-1345 (Print) 0041-1345 (Linking)

Ickx, B., Walker, S. \& Farman, J. V. (1987). Ionized calcium levels during liver transplantation. Eur J Anaesthesiol, 4, 6, (Nov,1987), pp. 421-427,0265-0215 (Print) 0265-0215 (Linking)

Jawan, B., de Villa, V., Luk, H. N., Chen, Y. S., Chiang, Y. C., Wang, C. C., Wang, S. H., Cheng, Y. F., Huang, T. L., Eng, H. L., Liu, P. P. \& Chen, C. L. (2003). Ionized calcium changes during living-donor liver transplantation in patients with and without administration of blood-bank products. Transpl Int, 16, 7, (Jul,2003), pp. 510-514,0934-0874 (Print) 0934-0874 (Linking)

Jugan, E., Albaladejo, P., Jayais, P. \& Ecoffey, C. (1992). The failure of venovenous bypass to prevent graft liver postreperfusion syndrome. Transplantation, 54, 1, (Jul,1992), pp. 81-84,0041-1337 (Print) 0041-1337 (Linking)

Kampmann, J. P., Sinding, J. \& Moller-Jorgensen, I. (1975). Effect of age on liver function. Geriatrics, 30, 8, (Aug,1975), pp. 91-95,0016-867X (Print)

Kawamoto, S., Tashiro, S., Miyauchi, Y. \& Inoue, M. (1991). Mechanism for enterohepatic injury caused by circulatory disturbance of hepatic vessels in the rat. Proc Soc Exp Biol Med, 198, 1, (Oct,1991), pp. 629-635,0037-9727 (Print) 0037-9727 (Linking)

Kirov, M. Y., Evgenov, O. V., Evgenov, N. V., Egorina, E. M., Sovershaev, M. A., Sveinbjornsson, B., Nedashkovsky, E. V. \& Bjertnaes, L. J. (2001). Infusion of 
methylene blue in human septic shock: a pilot, randomized, controlled study. Crit Care Med, 29, 10, (Oct,2001), pp. 1860-1867,0090-3493 (Print) 0090-3493 (Linking)

Ko, J. S., Kim, G. S., Gwak, M. S., Yang, M., Kim, H. K., Shin, B. S., Kim, J. K. \& Lee, S. K. (2008). Greater hemodynamic instability with histidine-tryptophan-ketoglutarate solution than University of Wisconsin solution during the reperfusion period in living donor liver transplantation. Transplant Proc, 40, 10, (Dec,2008), pp. 33083310,0041-1345 (Print) 0041-1345 (Linking)

Kulpmann, W. R., Rademacher, E. \& Bornscheuer, A. (1996). Ionized magnesium concentration during liver transplantation, resection of the liver and cardiac surgery. Scand J Clin Lab Invest Suppl, 224, 1996), pp. 235-243,0085-591X (Print) 0085$591 X$ (Linking)

Leggett, R. W. \& Williams, L. R. (1991). Suggested reference values for regional blood volumes in humans. Health Phys, 60, 2, (Feb,1991), pp. 139-154,0017-9078 (Print) 0017-9078 (Linking)

Leight, L., Roush, G., Rafi, E. \& McGaff, C. J. (1963). The Effect of Intravenous Potassium on Myocardial Contractility and Cardiac Dynamics. Am J Cardiol, 12, (Nov,1963), pp. 686-691,0002-9149 (Print) 0002-9149 (Linking)

Marczin, N., Tekeres, M., Salzman, A. L. \& Szabo, C. (1995). Methylene blue infusion in septic shock. Crit Care Med, 23, 11, (Nov,1995), pp. 1936-1938,0090-3493 (Print) 00903493 (Linking)

Marino, I. R. \& De Luca, G. (1985). Orthotopic liver transplantation in pigs. An evaluation of different methods of avoiding the revascularization syndrome. Transplantation, 40, 5, (Nov,1985), pp. 494-498,0041-1337 (Print) 0041-1337 (Linking)

Marquez, J., Martin, D., Virji, M. A., Kang, Y. G., Warty, V. S., Shaw, B., Jr., Sassano, J. J., Waterman, P., Winter, P. M. \& Pinsky, M. R. (1986). Cardiovascular depression secondary to ionic hypocalcemia during hepatic transplantation in humans. Anesthesiology, 65, 5, (Nov,1986), pp. 457-461,0003-3022 (Print) 0003-3022 (Linking)

Marzi, I., Knee, J., Menger, M. D., Harbauer, G. \& Buhren, V. (1991). Hepatic microcirculatory disturbances due to portal vein clamping in the orthotopic rat liver transplantation model. Transplantation, 52, 3, (Sep,1991), pp. 432-436,0041-1337 (Print) 0041-1337 (Linking)

Moreno, C., Sabate, A., Figueras, J., Camprubi, I., Dalmau, A., Fabregat, J., Koo, M., Ramos, E., Llado, L. \& Rafecas, A. (2006). Hemodynamic profile and tissular oxygenation in orthotopic liver transplantation: Influence of hepatic artery or portal vein revascularization of the graft. Liver Transpl, 12, 11, (Nov,2006), pp. 1607-1614,15276465 (Print) 1527-6465 (Linking)

Nanashima, A., Pillay, P., Crawford, M., Nakasuji, M., Verran, D. J. \& Painter, D. (2001). Analysis of postrevascularization syndrome after orthotopic liver transplantation: the experience of an Australian liver transplantation center. J Hepatobiliary Pancreat Surg, 8, 6, 2001), pp. 557-563,0944-1166 (Print) 0944-1166 (Linking)

Oishi, M., Tanaka, N. \& Orita, K. (1996). Beneficial effects of prostaglandin E1 on hemodynamic changes during liver transplantation in pigs. Transpl Int, 9 Suppl 1, 1996), pp. S100-104,0934-0874 (Print) 0934-0874 (Linking)

Olschewski, P., Gass, P., Ariyakhagorn, V., Jasse, K., Hunold, G., Menzel, M., Schoning, W., Schmitz, V., Neuhaus, P. \& Puhl, G. (2010). The influence of storage temperature 
during machine perfusion on preservation quality of marginal donor livers. Cryobiology, 60, 3, (Jun,2010), pp. 337-343,1090-2392 (Electronic) 0011-2240 (Linking)

Paugam-Burtz, C., Kavafyan, J., Merckx, P., Dahmani, S., Sommacale, D., Ramsay, M., Belghiti, J. \& Mantz, J. (2009). Postreperfusion syndrome during liver transplantation for cirrhosis: outcome and predictors. Liver Transpl, 15, 5, (May,2009), pp. 522-529,1527-6473 (Electronic) 1527-6465 (Linking)

Pertejo, M. A., Torres, J. G., Gillem, P. G., Jimenez, J. C., Rodriguez, F. S., Argente, G. R. \& Aleixandre, I. S. (2007). Initial poor function in the age of old donors: prognostic factors. Transplant Proc, 39, 7, (Sep,2007), pp. 2109-2111,0041-1345 (Print) 0041-1345 (Linking)

Pittet, J. F., Morel, D. R., Mentha, G., Le Coultre, C., Suter, P. M. \& Rohner, A. (1991). Protective effect of indomethacin in the development of the postreperfusion syndrome during liver transplantation in pigs. Transplant Proc, 23, 4, (Aug,1991), pp. 2290-2296,0041-1345 (Print) 0041-1345 (Linking)

Preiser, J. C., Lejeune, P., Roman, A., Carlier, E., De Backer, D., Leeman, M., Kahn, R. J. \& Vincent, J. L. (1995). Methylene blue administration in septic shock: a clinical trial. Crit Care Med, 23, 2, (Feb,1995), pp. 259-264,0090-3493 (Print) 0090-3493 (Linking)

Pretto, E. A., Jr. (2006). Perioperative management of the recipient of the extended criteria cadaveric donor liver (ECDL): a metabolic approach. Int Anesthesiol Clin, 44, 4, (Fall,2006), pp. 79-96,0020-5907 (Print) 0020-5907 (Linking)

Ronholm, E., Tomasdottir, H., Runeborg, J., Bengtsson, A., Bengtson, J. P., Stenqvist, O. \& Friman, S. (1994). Complement system activation during orthotopic liver transplantation in man. Indications of peroperative complement system activation in the gut. Transplantation, 57, 11, (Jun 15,1994), pp. 1594-1597,0041-1337 (Print) 0041-1337 (Linking)

Rull, R., Vidal, O., Momblan, D., Gonzalez, F. X., Lopez-Boado, M. A., Fuster, J., Grande, L., Bruguera, M., Cabrer, K. \& Garcia-Valdecasas, J. C. (2003). Evaluation of potential liver donors: limits imposed by donor variables in liver transplantation. Liver Transpl, 9, 4, (Apr,2003), pp. 389-393,1527-6465 (Print) 1527-6465 (Linking)

Ryu, H. G., Jung, C. W., Lee, C. S. \& Lee, J. (2011). Nafamostat mesilate attenuates Postreperfusion Syndrome during liver transplantation. Am J Transplant, 11, 5, (May,2011), pp. 977-983,1600-6143 (Electronic) 1600-6135 (Linking)

Sankary, H. N., Foster, P., Brown, E. \& Williams, J. (1996). Do splanchnic viscera contribute to liver preservation reperfusion injury? Transplantation, 61, 8, (Apr 27,1996), pp. 1142-1147,0041-1337 (Print) 0041-1337 (Linking)

Schneider, F. (1995). Methylene blue infusion in septic shock. Crit Care Med, 23, 11, (Nov,1995), pp. 1935-1936; author reply 1938,0090-3493 (Print) 0090-3493 (Linking)

Scott, V. L., De Wolf, A. M., Kang, Y., Altura, B. T., Virji, M. A., Cook, D. R. \& Altura, B. M. (1996). Ionized hypomagnesemia in patients undergoing orthotopic liver transplantation: a complication of citrate intoxication. Liver Transpl Surg, 2, 5, (Sep,1996), pp. 343-347,1074-3022 (Print) 1074-3022 (Linking)

Siniscalchi, A., Dante, A., Spedicato, S., Riganello, L., Zanoni, A., Cimatti, M., Pierucci, E., Bernardi, E., Miklosova, Z., Moretti, C. \& Faenza, S. (2010). Hyperdynamic circulation in acute liver failure: reperfusion syndrome and outcome following liver transplantation. Transplant Proc, 42, 4, (May,2010), pp. 1197-1199,1873-2623 (Electronic) 0041-1345 (Linking) 
Steininger, R., Roth, E., Fugger, R., Winkler, S., Langle, F., Grunberger, T., Gotzinger, P., Sautner, T. \& Muhlbacher, F. (1994). Transhepatic metabolism of TNF-alpha, IL-6, and endotoxin in the early hepatic reperfusion period after human liver transplantation. Transplantation, 58, 2, (Jul 27,1994), pp. 179-183,0041-1337 (Print) 0041-1337 (Linking)

Therapondos, G., Flapan, A. D., Plevris, J. N. \& Hayes, P. C. (2004). Cardiac morbidity and mortality related to orthotopic liver transplantation. Liver Transpl, 10, 12, (Dec,2004), pp. 1441-1453,1527-6465 (Print) 1527-6465 (Linking)

Tzakis, A., Todo, S. \& Starzl, T. E. (1989). Orthotopic liver transplantation with preservation of the inferior vena cava. Ann Surg, 210, 5, (Nov,1989), pp. 649-652,0003-4932 (Print) 0003-4932 (Linking)

Yersiz, H., Shaked, A., Olthoff, K., Imagawa, D., Shackleton, C., Martin, P. \& Busuttil, R. W. (1995). Correlation between donor age and the pattern of liver graft recovery after transplantation. Transplantation, 60, 8, (Oct 27,1995), pp. 790-794,0041-1337 (Print) 0041-1337 (Linking) 


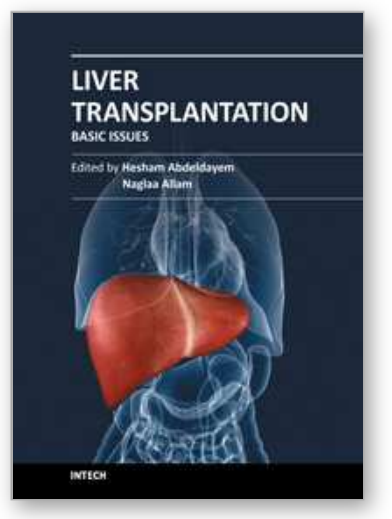

\author{
Liver Transplantation - Basic Issues \\ Edited by Prof. Hesham Abdeldayem
}

ISBN 978-953-51-0016-4

Hard cover, 418 pages

Publisher InTech

Published online 15, February, 2012

Published in print edition February, 2012

This book covers a wide spectrum of topics including history of liver transplantation, ischemia-reperfusion injury, immunology of liver transplantation, viral hepatitis and liver transplantation, other indications for liver transplantation, prognostic factors and perioperative period. The authors of the chapters are experts in their respective fields. They are proponents covering different aspects of liver transplantation and come from many centers across the world. The interdisciplinary approach and the authority of the contributors resulted in a valuable reference to anyone interested in developing a global view in liver transplantation including medical students, residents, fellows, nurses, and practicing physicians and surgeons as well as researchers in the field of liver transplantation.

\title{
How to reference
}

In order to correctly reference this scholarly work, feel free to copy and paste the following:

Kyota Fukazawa and Ernesto A. Pretto, Jr. (2012). The Post-Reperfusion Syndrome (PRS): Diagnosis, Incidence and Management, Liver Transplantation - Basic Issues, Prof. Hesham Abdeldayem (Ed.), ISBN: 978-953-51-0016-4, InTech, Available from: http://www.intechopen.com/books/liver-transplantation-basicissues/the-post-reperfusion-syndrome-prs-diagnosis-incidence-and-management

\section{INTECH}

open science | open minds

\section{InTech Europe}

University Campus STeP Ri

Slavka Krautzeka 83/A

51000 Rijeka, Croatia

Phone: +385 (51) 770447

Fax: +385 (51) 686166

www.intechopen.com

\section{InTech China}

Unit 405, Office Block, Hotel Equatorial Shanghai

No.65, Yan An Road (West), Shanghai, 200040, China

中国上海市延安西路65号上海国际贵都大饭店办公楼405单元

Phone: +86-21-62489820

Fax: +86-21-62489821 
(C) 2012 The Author(s). Licensee IntechOpen. This is an open access article distributed under the terms of the Creative Commons Attribution 3.0 License, which permits unrestricted use, distribution, and reproduction in any medium, provided the original work is properly cited. 